\title{
KEMAMPUAN MAHASISWA \\ DALAM MELAKSANAKAN KOMPETENSI GURU PROFESIONAL \\ PADA PEMBELAJARAN DISKUSI KELAS BERBASIS DISKUSI KELOMPOK INTUITIF MATA KULIAH SISTEM GEOMETRI
}

\author{
Fatriya Adamura \\ FPMIPA IKIP PGRI Madiun \\ (fat3ya_adamura@yahoo.co.id)
}

\begin{abstract}
Abstrak
Mahasiswa di Prodi Pendidikan Matematika untuk menguasai geometri secara mendalam sekaligus menguasai empat kompetensi guru profesional. Akan tetapi penguasaan materi sistem geometri dan kompetensi guru profesional masih kurang, sehingga mahasiswa perlu dilatih untuk berpikir intuitif dan menguasai kompetensi guru profesional. Salah satu pembelajaran yang melatih mahasiswa untuk berpikir intuitif dan menerapkan kompetensi guru profesional adalah pembelajaran diskusi kelas berbasis proses berpikir intuitif. Berdasarkan hal tersebut, maka perlu dilakukan penelitian untuk mendeskripsikan kemampuan mahasiswa dalam melaksanakan kompetensi guru profesional pada pembelajaran diskusi kelas berbasis diskusi kelompok intuitif mata kuliah sistem geometri.

Penelitian ini dilakukan dengan Lesson Study sebanyak empat siklus. Subyek Penelitian meliputi 40 orang mahasiswa kelas III G Prodi Pendidikan Matematika IKIP PGRI Madiun, seorang dosen model, dan tiga orang pengamat.

Hasil penelitian menunjukkan bahwa banyaknya kemampuan guru profesional yang belum terlaksana dengan baik pada Do I, Do II, dan Do III di pembelajaran diskusi kelas berbasis diskusi kelompok intuitif secara berturut-turut adalah dua, tiga, dan empat kemampuan dari delapan kemampuan guru profesional yang diamati. Sedangkan pada Do IV, semua kemampuan guru profesional yang diamati bisa dilakukan dengan baik oleh mahasiswa.
\end{abstract}

Kata kunci: kompetensi guru profesional, pembelajaran diskusi kelas, proses berpikir intuitif, sistem geometri

\section{PENDAHULUAN}

Berdasarkan KTSP tahun 2006, persentase aspek bilangan, aljabar, geometri dan pengukuran, serta statistika dan peluang yang dipelajari pada satuan SMP/MTs berturut-turut $15,25 \%, 37,29 \%, 40,68 \%$, serta 6,78\%. Hal itu menunjukkan bahwa geometri adalah salah satu aspek yang penting dalam Matematika Sekolah, khususnya pada satuan pendidikan SMP/MTs. 
Pentingnya aspek geometri tersebut menyebabkan mahasiswa calon guru Matematika yang sedang menempuh kuliah di Prodi Pendidikan Matematika harus menguasai materi geometri secara mendalam. Selain menguasai materi geometri secara mendalam, mahasiswa calon guru Matematika juga harus menguasai empat kompetensi guru profesional yang sangat berguna ketika mahasiswa terjun ke lapangan. Empat kompetensi guru profesional tersebut adalah kompetensi pedagogik, profesional, kepribadian, dan sosial (Sagala, 2009). Kompetensi pedagogik merupakan kemampuan mengelola pembelajaran, kompetensi profesional merupakan kemampuan berkepribadian yang mantap, berakhlak mulia, arif, dan berwibawa, serta menjadi teladan bagi peserta didik, dan kompetensi sosial merupakan kemampuan untuk berkomunikasi dan berinteraksi secara efektif dan efisien (UU RI No. 14 Tahun 2005).

Hal yang telah diuraikan di atas bertentangan dengan yang telah terjadi di lapangan. Ketika peneliti mengampu mata kuliah Sistem Geometri, ternyata ketuntasan belajar klasikal belum tercapai secara optimal. Hal ini terjadi karena peneliti belum menggunakan pembelajaran berbasis proses berpikir intuitif, padahal materi-materi pada geometri hanya bisa dipelajari secara intuitif (Hirawan, 2007). Ketika peneliti mengampu mata kuliah Pembelajaran Mikro (Microteaching), ternyata masih ada mahasiswa yang belum menguasai kompetensi guru profesional secara optimal.

Kemampuan berpikir intuitif tidak akan dimiliki mahasiswa secara tiba-tiba karena ada beberapa hal yang mempengaruhi berpikir intuitif. Beberapa hal yang memengaruhi berpikir intuitif, diantaranya: struktur pengetahuan, penguasaan bahan faktor pendidik, prosedur heuristik, dan menerka (Nasution, 2006). Hal-hal yang mempengaruhi berpikir intuitif tersebut perlu dilatihkan agar mahasiswa mampu menggunakannya dengan baik. Salah satu cara melatihkan berpikir intuitif adalah dengan menggunakan Lembar Kerja Mahasiswa (LKM) yang berbasis proses berpikir intuitif. Sedangkan pembelajaran yang bisa melatihkan kompetensi guru profesional adalah pembelajaran diskusi kelas berbasis diskusi kelompok. Pada pembelajaran diskusi kelas berbasis diskusi kelompok, mahasiswa dilatih untuk membangun sendiri 
materi yang dipelajari pada diskusi kelompok, kemudian mendiskusikan materi yang telah didapatkan secara klasikal pada diskusi kelas.

Berdasarkan uraian di atas, maka peneliti tertarik untuk melakukan penelitian yang bertujuan untuk mendeskripsikan kemampuan mahasiswa dalam melaksanakan kompetensi guru profesional pada pembelajaran diskusi kelas berbasis diskusi kelompok intuitif mata kuliah sistem geometri.

Penelitian ini dilakukan dengan menggunakan Lesson Study pada mata kuliah Sistem Geometri. Subyek penelitian adalah mahasiswa semester III pada kelas III G sebanyak 40 mahasiswa, seorang dosen model, dan tiga orang pengamat. Lesson Study dilaksanakan sebanyak empat kali siklus. Setiap siklus terdiri dari tiga kegiatan, yaitu: Plan, Do, dan See (Kurniadi, 2011).

Data yang dikumpulkan adalah data pelaksanaan Lesson Study seta data kemampuan siswa dalam melaksanakan empat kompetensi guru profesional. Data dikumpulkan dengan menggunakan teknik observasi (pengamatan). Data pelaksanaan Lesson Study dikumpulkan menggunakan Lembar Observasi Pembelajaran dalam Kegiatan Lesson Study, sedangkan data kemampuan siswa dalam melaksanakan empat kompetensi guru profesional dikumpulkan menggunakan lembar pengamatan kompetensi guru profesional. Teknik analisis data yang digunakan adalah pengumpulan data, reduksi data, sajian data, dan penarikan kesimpulan.

\section{PEMBAHASAN}

\section{A. Kemampuan Mahasiswa dalam Melaksanakan Kompetensi Guru Profesional pada Do I}

Pelaksanaan Plan I dalam mempersiapkan penerapan metode diskusi pada materi geometri sebagai suatu sistem deduktif (pada Do I) menghasilkan:

a. Kesepakatan, meliputi:

1) Sesuai dengan indikator, pembelajaran direncanakan menggunakan metode diskusi, resitasi, dan pemberian tugas.

2) Pembentukan kelompok harus dilakukan sebelum pembelajaran berlangsung. Pembentukan kelompok harus memperhatikan tingkat kecerdasan setiap 
mahasiswa agar mahasiswa yang berada pada kelompok yang sama adalah mahasiswa yang beragam tingkat kecerdasannya.

3) Aktivitas membaca buku sumber tidak dilakukan pada kegiatan saat pembelajaran berlangsung, tetapi dilakukan di rumah.

b. Instrumen pembelajaran yang disepakati, meliputi: SAP dengan metode pembelajaran diskusi, resitasi, dan pemberian tugas, Lembar Kerja Mahasiswa 1 (LKM 1), Lampiran RPP terdiri dari: Form Pengamatan Diskusi

Data kemampuan mahasiswa dalam melaksanakan empat kompetensi guru profesional pada Do I dapat dilihat pada Tabel 1 berikut.

Tabel 1. Rata-rata Kemampuan Mahasiswa dalam Melaksanakan Kompetensi Guru Profesional (Kemampuan Pedagogik, Profesional, Kepribadian, dan Sosial) pada Do I

\begin{tabular}{|c|c|c|c|c|c|c|}
\hline Kemampuan & 1 & 2 & 3 & 4 & 5 & 6 \\
\hline Nilai Rata-rata & 2,8 & 3,3 & 3 & 3 & 3 & 2, \\
\hline \multicolumn{7}{|l|}{ Keterangan: } \\
\hline Kemampuan 1 & \multicolumn{6}{|c|}{$\begin{array}{l}\text { : Kemampuan mengelola diskusi dengan baik } \\
\text { (Kemampuan Pedagogik) }\end{array}$} \\
\hline Kemampuan 2 & \multicolumn{6}{|c|}{$\begin{array}{l}\text { Kemampuan menguasai materi secara luas dan mendalam } \\
\text { (Kemampuan Profesional) }\end{array}$} \\
\hline Kemampuan 3 & \multicolumn{6}{|c|}{$\begin{array}{l}\text { : Kemampuan berkepribadian yang mantap } \\
\text { (Kemampuan Kepribadian) }\end{array}$} \\
\hline Kemampuan 4 & \multicolumn{6}{|c|}{ : Kemampuan berakhlak mulia (Kemampuan Kepribadian) } \\
\hline Kemampuan 5 & \multicolumn{6}{|c|}{$\begin{array}{l}\text { : Kemampuan berperilaku arif dan bijaksana } \\
\text { (Kemampuan Kepribadian) }\end{array}$} \\
\hline Kemampuan 6 & \multicolumn{6}{|c|}{$\begin{array}{l}\text { : Kemampuan menjadi teladan bagi peserta diskusi yang lain } \\
\text { (Kemampuan Kepribadian) }\end{array}$} \\
\hline Kemampuan 7 & \multicolumn{6}{|c|}{$\begin{array}{l}\text { : Kemampuan berkomunikasi secara efektif dan efisien } \\
\text { (Kemampuan Sosial) }\end{array}$} \\
\hline Kemampuan 8 & \multicolumn{6}{|c|}{$\begin{array}{l}\text { Kemampuan berinteraksi secara efektif dan efisien } \\
\text { (Kemampuan Sosial) }\end{array}$} \\
\hline
\end{tabular}

Tabel 1 di atas menunjukkan bahwa ada enam kemampuan yang memiliki nilai rata-rata $\geq 3$ (baik) dan ada dua kemampuan yang memiliki nilai rata-rata $<3$. Hasil analisis data tersebut menunjukkan bahwa masih ada dua kemampuan yang belum terlaksana dengan baik karena nilai rata-rata dua kemampuan tersebut kurang dari 3.

Kedua kemampuan yang belum terlaksana dengan baik tersebut dibicarakan pada tahap See I untuk mendapatkan alternatif penyebab dan solusinya. Berdasarkan hasil See I, didapat data seperti yang tercantum pada Tabel 2 berikut.

Tabel 2. Data Kemampuan yang Belum Terlaksana dengan Baik beserta Indikator, Alternatif Penyebab, dan Alternatif Solusinya pada Do II berdasarkan Hasil See II

\begin{tabular}{|l|l|c|c|c|}
\hline No. & $\begin{array}{l}\text { Kemampuan yang } \\
\text { Belum Terlaksana }\end{array}$ & Indikator & Alternatif Penyebab & Alternatif Solusi \\
\hline
\end{tabular}




\begin{tabular}{|c|l|l|l|l|}
\hline & dengan Baik & & & \\
\hline 1 & $\begin{array}{l}\text { Kemampuan } \\
\text { mengelola diskusi } \\
\text { dengan baik }\end{array}$ & $\begin{array}{l}\text { Mahasiswa } \\
\text { merasa bingung } \\
\text { dan canggung } \\
\text { dalam berdiskusi. }\end{array}$ & $\begin{array}{l}\text { Dosen model belum } \\
\text { menyampaikan langkah- } \\
\text { langkah pelaksanaan } \\
\text { diskusi dengan jelas } \\
\text { kepada mahasiswa. }\end{array}$ & $\begin{array}{l}\text { Dosen } \\
\text { menyampaikan } \\
\text { langkah-langkah } \\
\text { diskusi secara lisan } \\
\text { dengan jelas. }\end{array}$ \\
\hline 2 & $\begin{array}{l}\text { Kemampuan menjadi } \\
\text { teladan bagi peserta } \\
\text { diskusi yang lain }\end{array}$ & $\begin{array}{l}\text { Mahasiswa } \\
\text { berdebat dalam } \\
\text { memilih } \\
\text { presenter. }\end{array}$ & $\begin{array}{l}\text { Dosen model belum } \\
\text { memilih } \\
\text { koordinator kelompok } \\
\text { untuk setiap kelompok. }\end{array}$ & $\begin{array}{l}\text { Setiap } \\
\text { harus } \\
\text { seorang komiliki } \\
\text { kelompok. }\end{array}$ \\
\hline
\end{tabular}

Tindakan perbaikan terhadap SAP mengacu pada hasil See I:

a) Memasukkan langkah menyampaikan aturan pelaksanaan diskusi pada kegiatan inti,

Menuliskan aturan pelaksanaan diskusi pada SAP.

\section{B. Kemampuan Mahasiswa dalam Melaksanakan Kompetensi Guru Profesional pada Do II}

Pelaksanaan Plan II dalam mempersiapakan penerapan model diskusi kelas pada materi postulat-postulat pada geometri Euclides (pada Do II) menghasilkan:

a. Kesepakatan meliputi:

1) Sesuai dengan indikator, pembelajaran direncanakan menggunakan model pembelajaran diskusi kelas.

2) Fase 1 (Menyampaikan tujuan dan mengatur setting) dan fase 2 (Mengarahkan diskusi) pada model pembelajaran diskusi kelas dimasukkan pada kegiatan pendahuluan.

3) Tujuan dan aturan-aturan pada pelaksanaan diskusi dituliskan pada SAP.

4) Fase 5 (Melakukan tanya jawab singkat tentang pelaksanaan diskusi) pada model pembelajaran diskusi kelas dimasukkan pada kegiatan akhir.

5) Aspek penilaian pada form pengamatan diskusi lebih diperinci.

b. Instrumen pembelajaran yang disepakati, meliputi: SAP dengan model pembelajaran diskusi kelas, Lembar Kerja Mahasiswa 2 (LKM 2), dan Form Pengamatan Diskusi.

Data kemampuan mahasiswa dalam melaksanakan empat kompetensi guru profesional pada Do II dapat dilihat pada Tabel 3 berikut. 
Tabel 3. Rata-rata Kemampuan Mahasiswa dalam Melaksanakan Kompetensi Guru Profesional (Kemampuan Pedagogik, Profesional, Kepribadian, dan Sosial) pada Do II

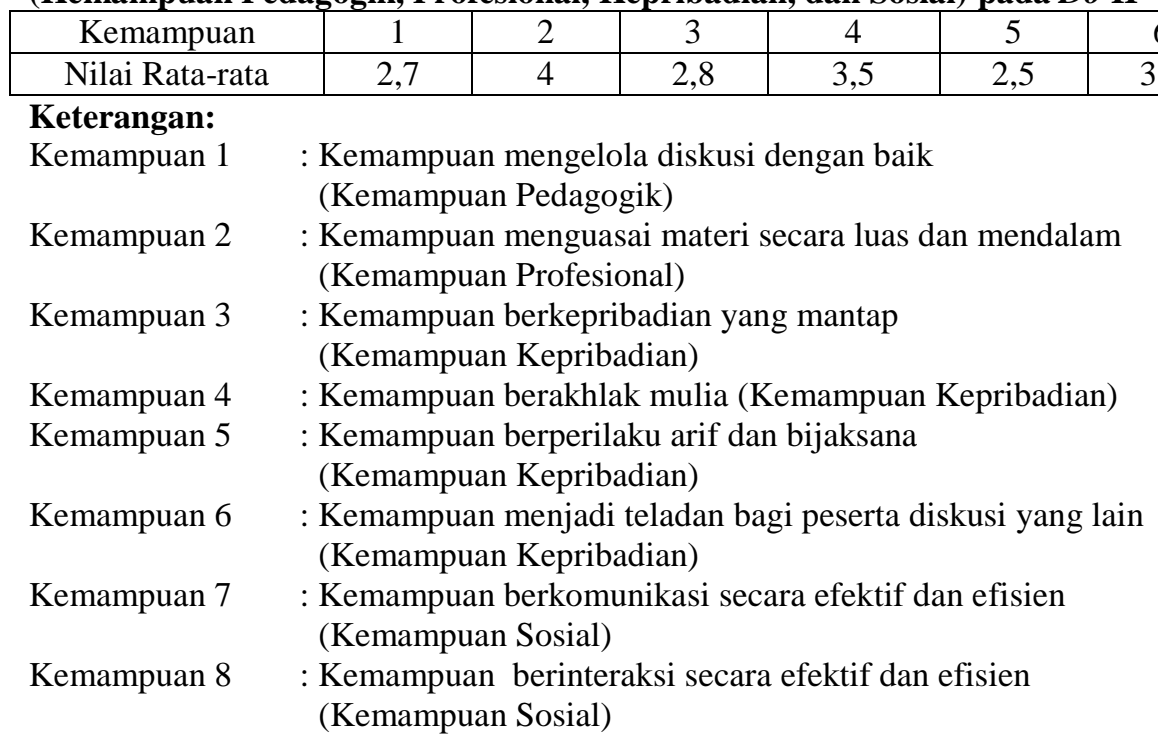

Tabel 3 di atas menunjukkan bahwa ada lima kemampuan yang memiliki nilai rata-rata $\geq 3$ (baik) dan ada tiga kemampuan yang memiliki nilai rata-rata $<3$. Hasil analisis data tersebut menunjukkan bahwa masih ada tiga kemampuan yang belum terlaksana dengan baik karena nilai rata-rata dua kemampuan tersebut kurang dari 3.

Ketiga kemampuan yang belum terlaksana dengan baik tersebut dibicarakan pada tahap See II untuk mendapatkan alternatif penyebab dan solusinya. Berdasarkan hasil See II, didapat data seperti yang tercantum pada Tabel 4 berikut.

Tabel 4. Data Kemampuan yang Belum Terlaksana dengan Baik beserta Indikator, Alternatif Penyebab, dan Alternatif Solusinya pada Do II berdasarkan Hasil See II

\begin{tabular}{|c|c|c|c|c|}
\hline No. & $\begin{array}{c}\text { Kemampuan yang } \\
\text { Belum Terlaksana } \\
\text { dengan Baik }\end{array}$ & Indikator & Alternatif Penyebab & Alternatif Solusi \\
\hline 1 & $\begin{array}{ll}\text { Kemampuan } & \\
\text { mengelola } & \text { diskusi } \\
\text { dengan baik } & \end{array}$ & $\begin{array}{l}\text { Setelah mahasiswa } \\
\text { menyampaikan } \\
\text { pendapat, } \\
\text { mahasiswa } \\
\text { tersebut diam dan } \\
\text { tidak } \\
\text { mempersilakan } \\
\text { temannya untuk } \\
\text { bertanya atau } \\
\text { menanggapi. }\end{array}$ & $\begin{array}{lr}\text { Dosen model belum } \\
\text { memasukkan langkah } \\
\text { bahwa mahasiswa yang } \\
\text { telah menyampaikan } \\
\text { solusi harus } \\
\text { mempersilakan } \\
\text { temannya untuk } \\
\text { bertanya ataupun } \\
\text { memberi tanggapan } \\
\text { pada langkah-langkah } \\
\text { pelaksanaan diskusi. }\end{array}$ & $\begin{array}{lr}\text { Dosen } & \text { model } \\
\text { memasukkan } & \\
\text { langkah bahwa } \\
\text { mahasiswa yang } \\
\text { telah menyampaikan } \\
\text { solusi harus } \\
\text { mempersilakan } \\
\text { temannya untuk } \\
\text { bertanya ataupun } \\
\text { memberi tanggapan } \\
\text { pada langkah- } \\
\text { langkah pelaksanaan } \\
\text { diskusi. }\end{array}$ \\
\hline 2 & $\begin{array}{l}\text { Kemampuan } \\
\text { berkepribadian yang }\end{array}$ & $\begin{array}{l}\text { Mahasiswa tidak } \\
\text { mau menjawab }\end{array}$ & $\begin{array}{l}\text { Dosen model belum } \\
\text { memberikan motivasi }\end{array}$ & $\begin{array}{lr}\text { Dosen } & \text { mendekati } \\
\text { dan } & \text { memberi }\end{array}$ \\
\hline
\end{tabular}




\begin{tabular}{|c|c|c|c|c|}
\hline & mantap & $\begin{array}{l}\text { masalah diskusi } \\
\text { dengan cepat. }\end{array}$ & $\begin{array}{l}\text { kepada mahasiswa yang } \\
\text { sudah menyampaikan } \\
\text { solusi atas masalah yang } \\
\text { disampaikan. }\end{array}$ & $\begin{array}{lr}\text { motivasi } & \text { kepada } \\
\text { mahasiswa } & \text { ketika } \\
\text { mahasiswa } & \\
\text { memikirkan } & \text { solusi } \\
\text { atas masalah } & \text { yang } \\
\text { disampaikan. } & \\
\end{array}$ \\
\hline 3 & $\begin{array}{l}\text { Kemampuan } \\
\text { berperilaku arif dan } \\
\text { bijaksana }\end{array}$ & $\begin{array}{l}\text { Mahasiswa yang } \\
\text { merasa kegerahan } \\
\text { dan bosan } \\
\text { mengganggu } \\
\text { mahasiswa yang } \\
\text { lain. }\end{array}$ & $\begin{array}{l}\text { Mahsiswa duduk } \\
\text { membentuk huruf U, } \\
\text { padahal ruang kuliah } \\
\text { sangat sempit. }\end{array}$ & $\begin{array}{lr}\text { - } & \text { kuang } \\
\text { dipindah } & \\
\text { - Karena } & \text { tempat } \\
\text { duduk mahasiswa } & \text { yang berbentuk } \\
\text { huruf U terdiri dari } \\
\text { dua baris, maka } \\
\text { jarak antara baris } \\
\text { pertama dan kedua } \\
\text { dibuat lebih lebar. }\end{array}$ \\
\hline
\end{tabular}

Tindakan perbaikan terhadap SAP mengacu pada hasil See II:

a) Memasukkan langkah menunjuk mahasiswa untuk menyampaikan pendapat atau tanggapan pada kegiatan inti

b) Memasukkan kegiatan mendekati dan memberi motivasi kepada mahasiswa untuk menemukan solusi atas masalah diskusi pada kegiatan inti

\section{Kemampuan Mahasiswa dalam Melaksanakan Kompetensi Guru Profesional pada Do III}

Pelaksanaan Plan III dalam mempersiapakan penerapan model diskusi kelas pada materi teorema-teorema yang diturunkan dari Postulat Kesejajaran Euclides (pada Do III) menghasilkan:

a. Kesepakatan, meliputi:

1) Sesuai dengan indikator, pembelajaran direncanakan menggunakan model pembelajaran diskusi kelas.

2) Kegiatan mengatur tempat duduk mahasiswa dilakukan sebelum pembelajaran dimulai.

3) Masalah diskusi yang ada pada Lembar Kerja Mahasiswa tidak menggunakan bahasa "Buktikan teorema...". Bahasa yang digunakan adalah bahasa masalah biasa saja agar pada akhir diskusi tersebut mahasiswa bisa menyimpulkan bahwa masalah yang telah didiskusikan merupakan suatu teorema.

4) Aspek penilaian pada form pengamatan diskusi lebih diperinci. 
b. Instrumen pembelajaran, meliputi: SAP dengan model pembelajaran diskusi kelas, Lembar Kerja Mahasiswa 3 (LKM 3), Form Pengamatan Diskusi.

Data kemampuan mahasiswa dalam melaksanakan empat kompetensi guru profesional pada Do III dapat dilihat pada Tabel 5 berikut.

Tabel 5. Rata-rata Kemampuan Mahasiswa dalam Melaksanakan Kompetensi Guru Profesional (Kemampuan Pedagogik, Profesional, Kepribadian, dan Sosial) pada Do III

\begin{tabular}{|c|c|c|c|c|c|c|c|c|}
\hline Kemampuan & 1 & 2 & 3 & 4 & 5 & 6 & 7 & 8 \\
\hline Nilai Rata-rata & 2,7 & 3,2 & 3,5 & 3 & 2,8 & 2,8 & 3 & 2,8 \\
\hline
\end{tabular}

\section{Keterangan:}

Kemampuan 1 : Kemampuan mengelola diskusi dengan baik (Kemampuan Pedagogik)

Kemampuan 2 : Kemampuan menguasai materi secara luas dan mendalam (Kemampuan Profesional)

Kemampuan 3 : Kemampuan berkepribadian yang mantap (Kemampuan Kepribadian)

Kemampuan 4 : Kemampuan berakhlak mulia (Kemampuan Kepribadian)

Kemampuan 5 : Kemampuan berperilaku arif dan bijaksana

(Kemampuan Kepribadian)

Kemampuan 6 : Kemampuan menjadi teladan bagi peserta diskusi yang lain (Kemampuan Kepribadian)

Kemampuan 7 : Kemampuan berkomunikasi secara efektif dan efisien (Kemampuan Sosial)

Kemampuan 8 : Kemampuan berinteraksi secara efektif dan efisien (Kemampuan Sosial)

Tabel 5 di atas menunjukkan bahwa ada empat kemampuan yang memiliki nilai rata-rata $\geq 3$ (baik) dan empat kemampuan yang memiliki nilai rata-rata $<3$. Hasil analisis data tersebut menunjukkan bahwa masih ada empat kemampuan yang belum terlaksana dengan baik karena nilai rata-rata dua kemampuan tersebut kurang dari 3.

Keempat kemampuan yang belum terlaksana dengan baik tersebut dibicarakan pada tahap See III bersama pendamping pelaksanaan Lesson Study dari Dikti untuk mendapatkan alternatif penyebab dan solusinya. Berdasarkan hasil See III, didapat data seperti yang tercantum pada Tabel 6 berikut.

Tabel 6. Data Kemampuan yang Belum Terlaksana dengan Baik beserta Indikator, Alternatif Penyebab, dan Alternatif Solusinya pada Do III berdasarkan Hasil See III

\begin{tabular}{|c|c|c|c|c|}
\hline No. & $\begin{array}{l}\text { Kemampuan yang } \\
\text { Belum Terlaksana } \\
\text { dengan Baik }\end{array}$ & Indikator & Alternatif Penyebab & Alternatif Solusi \\
\hline 1 & $\begin{array}{l}\text { Kemampuan } \\
\text { mengelola diskusi } \\
\text { dengan baik }\end{array}$ & $\begin{array}{l}\text { Mahasiswa tidak } \\
\text { diskusi dengan } \\
\text { baik. }\end{array}$ & $\begin{array}{l}\text { Dosen model belum } \\
\text { menuliskan langkah- } \\
\text { langkah diskusi pada } \\
\text { LKM. }\end{array}$ & $\begin{array}{l}\text { Pada LKM diberikan } \\
\text { langkah-langkah } \\
\text { terbimbing. }\end{array}$ \\
\hline 2 & $\begin{array}{l}\text { Kemampuan } \\
\text { berperilaku arif dan }\end{array}$ & $\begin{array}{l}\text { Mahasiswa tidak } \\
\text { mau membaca }\end{array}$ & $\begin{array}{ll}\text { Dosen model } & \text { belum } \\
\text { memberikan } & \text { beban }\end{array}$ & $\begin{array}{cr}\text { - LKM } & \text { diberikan } \\
\text { pada } & \text { pertemuan }\end{array}$ \\
\hline
\end{tabular}




\begin{tabular}{|c|c|c|c|c|}
\hline & bijaksana & $\begin{array}{l}\text { buku yang } \\
\text { seharusnya sudah } \\
\text { dibaca sebelum } \\
\text { pembelajaran } \\
\text { dimulai. }\end{array}$ & $\begin{array}{lr}\text { tugas yang mengikat } \\
\text { serta sanksi } & \text { atas } \\
\text { pengingkaran } & \text { beban } \\
\text { tugas tersebut. } & \end{array}$ & $\begin{array}{l}\text { sebelumnya. } \\
\text { Kemudian } \\
\text { mahasiswa diminta } \\
\text { untuk mencari } \\
\text { solusi atas masalah } \\
\text { tersebut sekaligus } \\
\text { membuat rancangan } \\
\text { slide yang akan } \\
\text { dipresentasikan. }\end{array}$ \\
\hline 3 & $\begin{array}{l}\text { Kemampuan menjadi } \\
\text { teladan bagi peserta } \\
\text { diskusi yang lain }\end{array}$ & $\begin{array}{l}\text { Mahasiswa sudah } \\
\text { ditunjuk oleh } \\
\text { dosen untuk } \\
\text { menyampaikan } \\
\text { pendapat sebagai } \\
\text { solusi atas masalah } \\
\text { diskusi yang } \\
\text { disampaikan, } \\
\text { tetapi mahasiswa } \\
\text { tersebut tetap tidak } \\
\text { mau menyampaikan } \\
\text { pendapatnya. }\end{array}$ & $\begin{array}{l}\text { Mahasiswa merasa ragu } \\
\text { atas pendapat yang } \\
\text { dimiliki. }\end{array}$ & $\begin{array}{l}\text { - Dosen meminta } \\
\text { mahasiswa untuk } \\
\text { menuliskan jawaban } \\
\text { di LKM, kemudian } \\
\text { mepresentasikan } \\
\text { jawaban tersebut di } \\
\text { depan kelas. } \\
\text { - LKM diganti } \\
\text { dengan kertas } \\
\text { manila agar materi } \\
\text { yang k dipesentasikan } \\
\text { dipresertas } \\
\text { ditulis dulu di kertas } \\
\text { manila, kemudian } \\
\text { dipresentasikan } \\
\text { dengan cara } \\
\text { membaca tulisan di } \\
\text { kertas manila di } \\
\text { depan kelas. }\end{array}$ \\
\hline 4 & $\begin{array}{l}\text { Kemampuan } \\
\text { berinteraksi secara } \\
\text { efektif dan efisien }\end{array}$ & $\begin{array}{l}\text { - Ketika mahasiswa } \\
\text { menjelaskan } \\
\text { pendapatnya } \\
\text { dengan } \\
\text { menggunakan } \\
\text { gambar, } \\
\text { mahasiswa hanya } \\
\text { melihat } \\
\text { gambarnya tanpa } \\
\text { memerhatikan } \\
\text { teman yang lain. } \\
\text { - Ketika mahasiswa } \\
\text { yang } \\
\text { menyampaikan } \\
\text { pendapatnya tadi } \\
\text { ditanya oleh } \\
\text { temannya, } \\
\text { mahasiswa } \\
\text { tersebut tidak bisa } \\
\text { menjawab. }\end{array}$ & \begin{tabular}{lr} 
- Mahasiswa & belum \\
\multicolumn{2}{l}{ benar-benar memahami } \\
pembuktian \\
disampaikan. \\
- Dosen belum memberi \\
contoh & cara \\
pembuktian yang \\
sistematis dan tepat \\
\multicolumn{2}{l}{ kepada mahasiswa. }
\end{tabular} & $\begin{array}{lr}\text { - Dosen } & \text { model } \\
\text { memberi } & \text { contoh } \\
\text { pembuktian } & \text { terlebih } \\
\text { dahulu } & \text { kepada } \\
\text { mahasiswa untuk } & \text { melatih mahasiswa } \\
\text { berpikir analogis. }\end{array}$ \\
\hline
\end{tabular}

Tindakan perbaikan terhadap SAP mengacu pada hasil See III:

a) Memasukkan langkah memberikan contoh pembuktian di awal kegiatan inti. 
b) Memasukkan langkah memberikan dan meminta mahasiswa mengerjakan LKM pada pertemuan sebelumnya.

c) Memasukkan langkah memberikan tambahan nilai bagi mahasiswa yang telah menyampaikan pendapat ataupun tanggapan.

\section{Kemampuan Mahasiswa dalam Melaksanakan Kompetensi Guru Profesional pada Do IV}

Pelaksanaan Plan IV dalam mempersiapakan penerapan model diskusi kelas pada materi Postulat-postulat pengganti Postulat Kesejajaran Euclides (pada Do IV) menghasilkan:

a. Kesepakatan, meliputi:

1) Sesuai dengan indikator, pembelajaran direncanakan menggunakan model pembelajaran diskusi kelas.

2) Model tempat duduk yang digunakan adalah mahasiswa duduk berdekatan kelompok. Model tempat duduk kelompok-kelompok mahasiswa berbentuk huruf $\mathrm{U}$.

3) Kelompok yang dibentuk sebanyak 14 kelompok. setiap kelompok beranggotakan tiga orang mahasiswa.

4) Semua kelompok diberi tugas untuk menyelesaikan semua masalah, tetapi secara khusus, kelompok mahasiswa 1 s/d 4 membuktikan ekivalensi Postulat Kesejajaran Euclides dengan Postulat Playfair jika diketahui Postulat Kesejajaran Euclides, kelompok mahasiswa 5 s/d 6 membuktikan ekivalensi Postulat Kesejajaran Euclides dengan Postulat Playfair jika diketahui Postulat Playfair, kelompok mahasiswa 7 s/d 9 membuktikan ekivalensi Postulat Kesejajaran Euclides dengan Postulat Proclus jika diketahui Postulat Proclus.

b. Instrumen pembelajaran yang digunakan meliputi: Silabus, SAP dengan model pembelajaran diskusi kelas, Lembar Kerja Mahasiswa 4 (LKM 4), dan Form Pengamatan Diskusi.

Data kemampuan mahasiswa dalam melaksanakan empat kompetensi guru profesional pada Do IV dapat dilihat pada Tabel 7 berikut. 
Tabel 7. Rata-rata Kemampuan Mahasiswa dalam Melaksanakan Kompetensi Guru Profesional (Kemampuan Pedagogik, Profesional, Kepribadian, dan Sosial) pada Do III

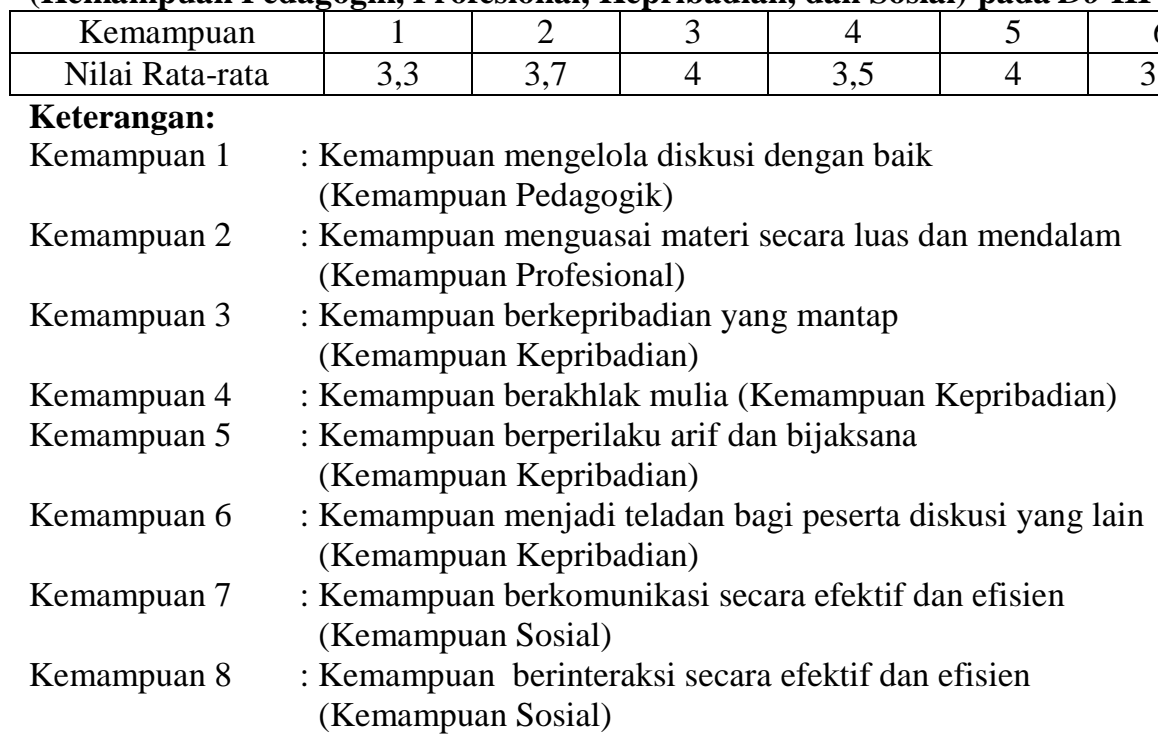

Tabel 7 di atas menunjukkan bahwa semua kemampuan memiliki nilai rata-rata $\geq$ 3 (baik). Hasil analisis data tersebut menunjukkan bahwa semua kemampuan sudah terlaksana dengan baik. Meskipun demikian, masih ada beberapa masalah yang dijumpai pada pelaksanaan Do IV yang dibicarakan pada kegiatan See IV. Kegiatan See yang dilakukan dosen model bersama para pengamat menghasilkan temuan permasalahan mahasiswa dalam proses pembelajaran beserta solusinya (Tabel 8).

Tabel 8. Data Kemampuan yang Belum Terlaksana dengan Baik beserta Indikator, Alternatif Penyebab, dan Alternatif Solusinya pada Do III berdasarkan Hasil See III

\begin{tabular}{|c|c|c|}
\hline No. & Temuan Permasalahan & Solusi \\
\hline 1. & $\begin{array}{l}\text { Ada mahasiswa yang masih pasif dalam } \\
\text { mengikuti diskusi karena materi diskusi yang } \\
\text { dipresentasikan berbeda materi yang } \\
\text { diselesaikan oleh kelompok mahasiswa } \\
\text { tersebut. }\end{array}$ & $\begin{array}{l}\text { - Dosen model menyampaikan bahwa dalam } \\
\text { Matematika, materi yang satu merupakan } \\
\text { materi prasyarat untuk materi yang lain. } \\
\text { - Dosen model menjelaskan secara } \\
\text { menyeluruh bahwa konsep dalam setiap } \\
\text { masalah berkaitan. }\end{array}$ \\
\hline 2. & $\begin{array}{l}\text { Kelompok mahasiswa } 8 \text { tidak mengerjakan } \\
\text { LKM sama sekali. } \\
\text { Kemungkinan penyebab: } \\
\text { - Tidak ada konsekuensi jika tidak mengerjakan } \\
\text { - Mahasiswa sudah belajar, tapi belum paham }\end{array}$ & $\begin{array}{l}\text { - Kelompok yang tidak mengerjakan LKM } \\
\text { dipaksa untuk mempresentasikan solusi } \\
\text { atas masalah yang menjadi beban } \\
\text { kelompok tersebut. Jika kelompok tersebut } \\
\text { tidak bisa mempresentasikan apapun, maka } \\
\text { dosen model memberikan kesempatan } \\
\text { untuk kelompok lain untuk } \\
\text { mempresentasikan solusi atas masalah } \\
\text { yang tidak diselesaikan oleh kelompok } \\
\text { yang bertugas. }\end{array}$ \\
\hline
\end{tabular}

Tindakan perbaikan terhadap SAP mengacu pada hasil refleksi: 
a) Memasukkan langkah menyampaikan bahwa dalam Matematika, materi yang satu merupakan materi prasyarat untuk materi yang lain.

b) Memasukkan langkah menjelaskan secara menyeluruh bahwa konsep dalam setiap masalah berkaitan.

\section{KESIMPULAN}

Berdasarkan hasil penelitian, banyaknya kemampuan guru profesional yang belum terlaksana dengan baik pada Do I, Do II, dan Do III secara berturut-turut adalah dua, tiga, dan empat kemampuan dari delapan kemampuan guru profesional yang diamati. Sedangkan pada Do IV, semua kemampuan guru profesional yang diamati bisa dilakukan dengan baik oleh mahasiswa. Hal ini menunjukkan bahwa pembelajaran diskusi kelas berbasis diskusi kelompok intuitif pada mata kuliah sistem geometri merupakan pembelajaran yang dapat melatih kompetensi guru profesional kepada mahasiswa.

Saran yang dikemukakan berdasarkan hasil penelitian adalah pembelajaran diskusi kelas berbasis diskusi kelompok intuitif hendaknya dilakukan pada pembelajaran mata kuliah Sistem Geometri materi yang lain ataupun mata kuliah lain karena dapat melatihkan kompetensi guru profesional pada mahasiswa.

\section{DAFTAR PUSTAKA}

Hirawan, Amelia. 2007. Intuisi. (http://www.ameliahirawan.or.id/intuisi/, diakses 12 Nopember 2008)

Kurniadi, Erawan. Penerapan Pembelajaran Elektronika I Berbasis Konflik Kognitif melalui Metode Percobaan, Demonstrasi, Ceramah, dan Diskusi. Jurnal Pendidikan MIPA IKIP PGRI Madiun Vol. 3, No. 1. Maret 2011

Nasution, S.. 2006. Berbagai Pendekatan dalam Proses Belajar Mengajar. Jakarta: Bumi Aksara

Sagala, Syaiful. 2009. Kemampuan Profesional Guru dan Tenaga Kependidikan. Bandung: Alfabeta

Undang-undang tentang Guru dan Dosen No.14 Tahun 2005. Jakarta: Sinar Grafika 